$14^{\text {th }}$ Conf. Agric. Develop. Res., Fac. of Agric., Ain Shams Univ., March, 2019, Cairo, Egypt

Special Issue, 27(1), 175 - 183, 2019

Website: http://strategy-plan.asu.edu.eg/AUJASCI/

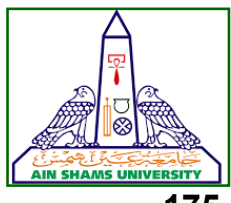

\title{
PHYSICO-CHEMICAL PROPERTIES OF SOME LISTERIA PHAGES
}

\author{
[16] \\ Yasmer S. Hussein ${ }^{1}$, Samar S. El-Masry ${ }^{1}$, Abeer A. Faiesal ${ }^{2}$, El-Dougdoug Kh.A. ${ }^{1}$ \\ and Othman B.A. ${ }^{1}$ \\ 1. Agric. Microbiology Dept., Fac. of Agric., Ain Shams Univ., P.O. Box 68, Hadayek Shobra \\ 11241, Cairo, Egypt \\ 2. Basic and Applied Agric. Sciences Dept., Higher Institute for Agric. Co-Operation, Cairo, \\ Egypt.
}

*Corresponding author: samar_sayed@agr.asu.edu.eg

Received 24 February, 2019, $\quad$ Accepted 9 April, 2019

\begin{abstract}
Listeria monocytogenes is a food borne pathogenic bacteria and caused a dangerous infection of humans. Six lytic bacteriophages specific to $L$. monocytogenes were isolated from irrigation and sewage waters and named $\varnothing \mathrm{LG}, \varnothing \mathrm{LA}, \varnothing \mathrm{LM}, \varnothing L D$, $\varnothing L N$ and $\varnothing L P$. The phages were propagated, and then purified by the ultracentrifugation. Morphological properties of Listeria phages showed that the phages were tailed phages, varied in their sizes and assigned to be a member of Siphoviridae (ØLG, ØLA, ØLM) and Myoviridae (ØLN, ØLD, $\varnothing L P)$ families. All Listeria phages were highly stable under different temperature conditions and its thermal inactivation point was reached to $80^{\circ} \mathrm{C}$. The longevity in vitro of the phages was up to 60 days, as well as phages were active at $\mathrm{pH}$ values ranging from 4.0 to 12.0 . Listeria phages did not lose their infectivity after exposure to UV for $90 \mathrm{~min}$ at 35 and $53 \mathrm{~cm}$ distances. Results of SDS-PAGE showed that phages had 5-6 protein fragments with molecular weights of $66,45,37,35,33$ and 28 $\mathrm{kDa}$ distributed among the six phages.
\end{abstract}

Key words: Listeria phages, sewage water, physico-chemical properties, SDS-PAGE.

\section{INTRODUCTION}

Listeria monocytogenes is one of the most common bacteria associated with food-borne illness and it is an opportunistic pathogen that causes listeriosis due to its ability to colonize the human gastrointestinal system (Klumpp and Loessner, 2013). They also showed that listeriosis is known for pregnant women infection, which later infects the fetus and often results in stillbirth or miscarriage. Eating of contaminated food is the most possible cause of $L$. monocytogenes infection (Hagens and Loessner, 2014). Listeria is a psychrotrophic microorganism, Therefore, killed at high temperatures such as $160^{\circ} \mathrm{F}$, but able to grow well at lower temperatures including refrigerator temperatures (Schmid et al 2009). Foods products like meat, dairy and soft cheeses are frequently contaminated with L. monocytogenes. Most countries applied law which required the absence of $L$. monocytogenes from $25 \mathrm{~g}$ of a food sample and apparently is a challenge for any detection system (Yutaka et al 2004).

Bacteriophages are considered a great weapon against pathogenic bacteria. There are more than 400 phages specific for genus of Listeria which have been isolated and characterized (Lossner and Rees, 2005 and Schmuki et al 2012). They also showed that most of the phages belongs to Siphoviridae family and only few to family Myoviridae.

This study aims to isolate and characterize Listeria phages depending on their physico-chemical properties.

\section{MATERIAL AND METHODS}

\section{Listeria monocytogenes source}

L. monocytogenes CRIFS LJH391 was obtained from Virology Lab., Agric. Microbiol. Dept., Fac. of Agric., Ain Shams Univ., Cairo, Egypt.

\section{Sources of water samples}

Eight samples of Nile and drange water were collected from different recourses such as canals 
(El-Sharkawya, Meet Nama, Ismailia, and ElMariotya), sewage treatment stations (El-Gabal Elasfar sewage, Passous, and Shoubra El-Khaima) and Water drainage system of Agricultural Faculty, Ain Shams University. Samples were directly transferred to the Virology Lab., Agric. Microbiol. Dept., Fac. of Agric., Ain Shams Univ., Cairo, Egypt. The samples were maintained at $4^{\circ} \mathrm{C}$ until used.

\section{Isolation of Listeria virulent phages:}

Sterile Erlenmeyer flask $250 \mathrm{ml}$ containing 50 $\mathrm{mL}$ of nutrient broth medium (2x) (Madigan and Martinko (2005) was inoculated with mixture of $5.0 \mathrm{~mL}$ of the tested water or sewage water samples and a volume of inoculated by $5.0 \mathrm{~mL}$ of overnight liquid culture of Listeria were added to each flask. The inoculated flasks were incubated at $37^{\circ} \mathrm{C}$ for $48 \mathrm{hrs}$ under shaking conditions (250 $\mathrm{rpm} / \mathrm{min})$. The inoculated cultures were centrifuged at $6000 \mathrm{rpm}$ for $15 \mathrm{~min}$ at $4^{\circ} \mathrm{C}$. The supernatants were collected into a clean flask. Chloroform was added at rate of $1: 10(\mathrm{v} / \mathrm{v})$ to the supernatants followed by vigorously shaking for $5.0 \mathrm{~min}$ and the crude phages lysates were transferred into a fresh tube.

The presence of bacteriophages specific to Listeria was detected in the crude phage lysates qualitatively by spot test technique according to the method of Borrego et al (1987). Phages were assayed quantitatively in the samples which gave positive results by the plaque assay method according to Othman, (1997).

\section{Listeria phage lysates propagation}

Listeria phage lysates were prepared by single plaque isolation (SIP) technique according to the method of Adams (1959). SPI was repeated three times until obtaining uniform plaque morphology of Listeria phage lysates. Propagation of the phage isolates on their liquid Listeria culture was carried out to obtain large amount of high titer Listeria phage stock as reported by Goodridge et al (2001).

\section{Listeria phages purification and concentration:}

The purified propagated Listeria phage isolates were concentrated using the differential centrifugation method of Figrski and Christensen (1974). Firstly, Listeria phage lysates were centrifuged at low speed at $6000 \mathrm{rpm}$ for $15 \mathrm{~min}$ at $4^{\circ} \mathrm{C}$. Secondly, supernatants were centrifuged using Backman
L 7-35 ultracentrifuge at $30000 \mathrm{rpm}$ for $90 \mathrm{~min}$ at $4^{\circ} \mathrm{C}$. The pellets were re-suspended in $300 \mu \mathrm{L}$ from CM buffer.

\section{Characterization of purified Listeria phages:}

To determine shape and size of Listeria phage particles were determined according to the method of Adams (1959). Five $\mu \mathrm{L}$ of Listeria phage suspension was placed onto 200 mesh cupper coated carbon grid, then examined using a JOEL-JEM 1010 electron microscope (Electron Microscope Unit, Regional Center for Mycology and Biotechnology, Al-Azhar Univ., Cairo, Egypt).

\section{Stability of Listeria phages}

The effect of temperature on the Listeria phages in vitro was determined by exposure the phage suspensions to different temperature degrees 30 , $40,50,60,70,80,90$ and $98^{\circ} \mathrm{C}$ for $10 \mathrm{~min}$. according to the method of Basdew and Laing (2014). $15 \mu \mathrm{L}$ from each treated Listeria phages were assayed qualitatively by the spot test technique Othman (1997).

Two $\mathrm{mL}$ of Listeria phage suspensions were pipetted in each Eppendorf tube. The tubes were left for 60 days at room temperature $\left(25-30^{\circ} \mathrm{C}\right)$ and refrigerator $\left(4^{\circ} \mathrm{C}\right)$. One tube was taken every 7 days and the phage suspension was assayed qualitatively for its infectivity by the spot test technique (Othman, (1997).

Effect of pH on Listeria phages:

The infectivity of Listeria phages were evaluated by exposure to adjusted $\mathrm{pH}$ values ranged from 4.0 to 12 using $0.1 \mathrm{~N} \mathrm{HCl}$ or $\mathrm{NaOH}$ for 12 and $24 \mathrm{hrs}$ at room temperature according to the method of Taj et al., (2014). After incubation Listeria phage lysates were neutralized and the activity was determined by the spot test method as mentioned before.

\section{Sensitivity of Listeria phages to UV irradiation}

Open Petri dishes each containing five $\mathrm{mL}$ of high titer Listeria phage suspensions $\left(10^{8} \mathrm{pfu} / \mathrm{mL}\right)$ were placed at different distances $(35$ and $53 \mathrm{~cm}$ ) and times $(15,30,45,60,75$, and $90 \mathrm{~min})$ from UV $(254 \mathrm{~nm})$ irradiation sources according to the protocol of Jamalludeen et al (2007). These, the suspensions of Listeria phages were assayed qualitatively by the spot test method. Ten $\mu \mathrm{L}$ of each irradiated suspensions of Listeria phages were spotted over double layer agar plates con- 
taining the listerial indicator bacteria host, incubated at $37^{\circ} \mathrm{C}$ for $16-24 \mathrm{~h}$ in upright positions. Then, plates were inspected for lysed spots.

\section{SDS-PAGE analysis of Listeria phages:}

SDS-PAGE analysis of Listeria phages were conducted as described by Laemmli, (1970). Listeria phage suspensions were centrifuged at $16000 \mathrm{rpm}$ for $90 \mathrm{~min}$ at $4^{\circ} \mathrm{C}$ and the pellets were collected and re-suspended in $1.0 \mathrm{~mL}$ resuspension buffer ( $1.0 \mathrm{mM} \mathrm{NaCl}, 5 \mathrm{mM}$ EDTA). One volume of phage suspension was mixed with an equal volume of $2 X$ treatment buffer containing BPB as a tracking dye and boiled in a water bath for $90 \mathrm{~s}$ then quickly transferred into ice water and kept until loading into the gel. Eequal amounts of proteins $(25 \mu \mathrm{L})$ of each sample were loaded in each well, and high range molecular weight protein marker was also loaded into a separate well. Electrophoresis was done at about $50 \mathrm{~V}(15 \mathrm{~mA})$ for running through stacking gel after that it was $120 \mathrm{v}$
(30 $\mathrm{mA}$ ) for running through separating gel in $1 \mathrm{x}$ Tris/glycine-SDS-running buffer. The gel was stained with Coomassie Brilliant Blue for overnight and destined with acetic acid glacial (Sambrook et al 1989).

\section{RESULTS}

\section{Isolation of Listeria virulent phages from differ- ent water sources}

Different samples of water and sewage water collected from different locations were used to isolate specific lytic Listeria phages. Spot test was successfully used to detect the presence of Listeria phages (Qualitatively) in the collected water samples (Table 1). Six out of the eight samples gave positive reactions confirmed the presence of Listeria phages. The positive samples were also assayed quantitatively using the plaque assay technique and the phages concentrations were noted as shown in (Table 1).

Table 1. Qualitative and quantitative assaying of Listeria lytic phages in water samples.

\begin{tabular}{|c|c|c|c|c|c|}
\hline Water sources & Locations & $\begin{array}{c}\text { Gover- } \\
\text { norates }\end{array}$ & $\begin{array}{c}\text { Phage } \\
\text { codes }\end{array}$ & $\begin{array}{c}\text { Qualitative as- } \\
\text { say (Spot test) }\end{array}$ & $\begin{array}{c}\text { Quantitative } \\
\text { assay } \\
(\mathrm{pfu} / \mathrm{mL})\end{array}$ \\
\hline \multirow{3}{*}{ Canals } & El-Sharkawya & El-Kalubia & - & - & 0.00 \\
& El-Esmailia & El-Kalubia & - & - & 0.00 \\
& Meet Nama & El-Kalubia & $\varnothing \mathrm{LN}$ & + & $3.0 \times 10^{4}$ \\
& El-Mariotya & Giza & $\varnothing \mathrm{LM}$ & + & $3.5 \times 10^{4}$ \\
\hline \multirow{2}{*}{ Sewage treat- } & El-Gabl El-Asfar & El-Kalubia & $\varnothing \mathrm{LG}$ & + & $4.0 \times 10^{4}$ \\
ment stations & Passous & El-Kalubia & $\varnothing \mathrm{LP}$ & + & $5.0 \times 10^{4}$ \\
& Shoubra Elkhema & El-Kalubia & $\varnothing \mathrm{LD}$ & + & $3.0 \times 10^{5}$ \\
\hline Water drainage & Fac. of Agri., Ain & El-Kalubia & $\varnothing \mathrm{LA}$ & + & $2.0 \times 10^{5}$ \\
\hline
\end{tabular}

- = no lysis (-ve result). + = lysis (+ve result). Ø: Phage. L.: Listeria. N: Meet Nama. M: El-Mariotya. G: El-Gabl ElAsfar. P: Passous. D: Shoubra El-Khaima.. A: Ain Shams University.

\section{Propagation, purification and plaques mor- phology of Listeria phages}

Single plaque isolation was done to obtain pure Listeria phage isolate. Only one plaque was picked up from each bacteriophage positive sample and concentrations of Listeria phages were determined. Listeria phage particles were purified and concentrated using the ultracentrifugation. High titer phage stock of the isolated Listeria phages was obtained by phage propagation several times by the liquid listerial culture method. Data in Table (2) showed that all the isolated phages have plaques with circular, clear shape with diameter ranged between 2 and $3 \mathrm{~mm}$. 
Table 2. Concentrations and plaques morphology of Listeria phages.

\begin{tabular}{|c|c|c|c|c|}
\hline Phages & $\begin{array}{c}\text { Plaque } \\
\text { diameters } \\
(\mathbf{m m})\end{array}$ & $\begin{array}{c}\text { Pres- } \\
\text { ence } \\
\text { of } \\
\text { halo* }^{*}\end{array}$ & $\begin{array}{c}\text { Plaque } \\
\text { shapes }\end{array}$ & $\begin{array}{c}\text { Concentra- } \\
\text { tions } \\
\text { (pfu/mL) }\end{array}$ \\
\hline$\varnothing \mathrm{LA}$ & $<2$ & + & clear, circular & $6 \times 10^{6}$ \\
$\varnothing \mathrm{LD}$ & 2 & + & clear, circular & $8 \times 10^{6}$ \\
$\varnothing \mathrm{LG}$ & $<2$ & + & clear, circular & $6.5 \times 10^{6}$ \\
$\varnothing \mathrm{LM}$ & 3 & + & clear, circular & $5 \times 10^{6}$ \\
$\varnothing \mathrm{LN}$ & 2 & + & clear, circular & $6.3 \times 10^{7}$ \\
$6.5 \times 10^{7}$ \\
$\varnothing \mathrm{LP}$ & 2 & + & clear, circular & $7 \times 10^{6}$ \\
\hline
\end{tabular}

${ }^{*}+=$ plaque was surrounded with halo.

\section{Morphology of Listeria phages}

Electron microscopy of the isolated Listeria phages are shown in Table (3) and illustrated by Fig. (1). Results showed that phage $\varnothing L G$ had isometric head with diameter of $69.2 \mathrm{~nm}$ and long noncontractile tail with length of $269.2 \mathrm{~nm}$ and width of $15.4 \mathrm{~nm}$, phage ØLA had isometric head with diameter of $80 \mathrm{~nm}$ and long noncontractile tail with length of $260 \mathrm{~nm}$ and width of $20 \mathrm{~nm}$. Phage $\varnothing L M$ had isometric head with diameter of $61.5 \mathrm{~nm}$ and long noncontractile tail with length of $207.7 \mathrm{~nm}$ and width of $7.7 \mathrm{~nm}$. Phage $\varnothing \mathrm{LN}$ had isometric head with diameter of $100 \mathrm{~nm}$ and long contractile tail with length of $156 \mathrm{~nm}$ and width of $22 \mathrm{~nm}$. Phage ØLD had an elongated head with diameter of $84.6 \times 92.3 \mathrm{~nm}$ and long contractile tail with length of $169.2 \mathrm{~nm}$ and width of $23.1 \mathrm{~nm}$. Phage $\varnothing \mathrm{LP}$ had isometric head with diameter of $100 \mathrm{~nm}$ and long contractile tail with length of $153.8 \mathrm{~nm}$ and width of $23.10 \mathrm{~nm}$. Based on the experimental results phages $\varnothing \mathrm{LG}, \varnothing L A$ and $\varnothing \mathrm{LM}$ were belonging to family Siphoviridae. Phages $\varnothing L N, \varnothing L D$ and $\varnothing \mathrm{LP}$ were belonging to family Myoviridae as indicated by tail characters of the phages.

Table 3. Sizes and morphology of Listeria phages particles.

\begin{tabular}{|c|c|c|c|c|}
\hline \multirow{2}{*}{$\begin{array}{l}\text { Listeria } \\
\text { phages }\end{array}$} & \multicolumn{2}{|c|}{ Heads } & \multicolumn{2}{|c|}{ Tails } \\
\hline & $\begin{array}{l}\text { Sizes } \\
(\mathrm{nm})\end{array}$ & Morphology & $\begin{array}{l}\text { Sizes } \\
(\mathrm{nm})\end{array}$ & Shapes \\
\hline$\varnothing L A$ & $80 \times 80$ & Isometric & $260 \times 20$ & $\begin{array}{l}\text { Long non- } \\
\text { contractile }\end{array}$ \\
\hline$\varnothing L D$ & $84.6 \times 92.3$ & Elongated & $169.2 \times 23.1$ & $\begin{array}{l}\text { Long con- } \\
\text { tractile }\end{array}$ \\
\hline$\varnothing L G$ & $69.2 \times 69.2$ & Isometric & $269.2 \times 15.4$ & $\begin{array}{l}\text { Long non- } \\
\text { contractile }\end{array}$ \\
\hline$\varnothing L M$ & $61.5 \times 61.5$ & Isometric & $207.7 \times 7.7$ & $\begin{array}{l}\text { Long non- } \\
\text { contractile }\end{array}$ \\
\hline$\varnothing L N$ & $100 \times 100$ & Isometric & $156 \times 22$ & $\begin{array}{l}\text { Long con- } \\
\text { tractile }\end{array}$ \\
\hline$\varnothing L P$ & $100 \times 100$ & Isometric & $153.8 \times 23.1$ & $\begin{array}{l}\text { Long con- } \\
\text { tractile }\end{array}$ \\
\hline
\end{tabular}

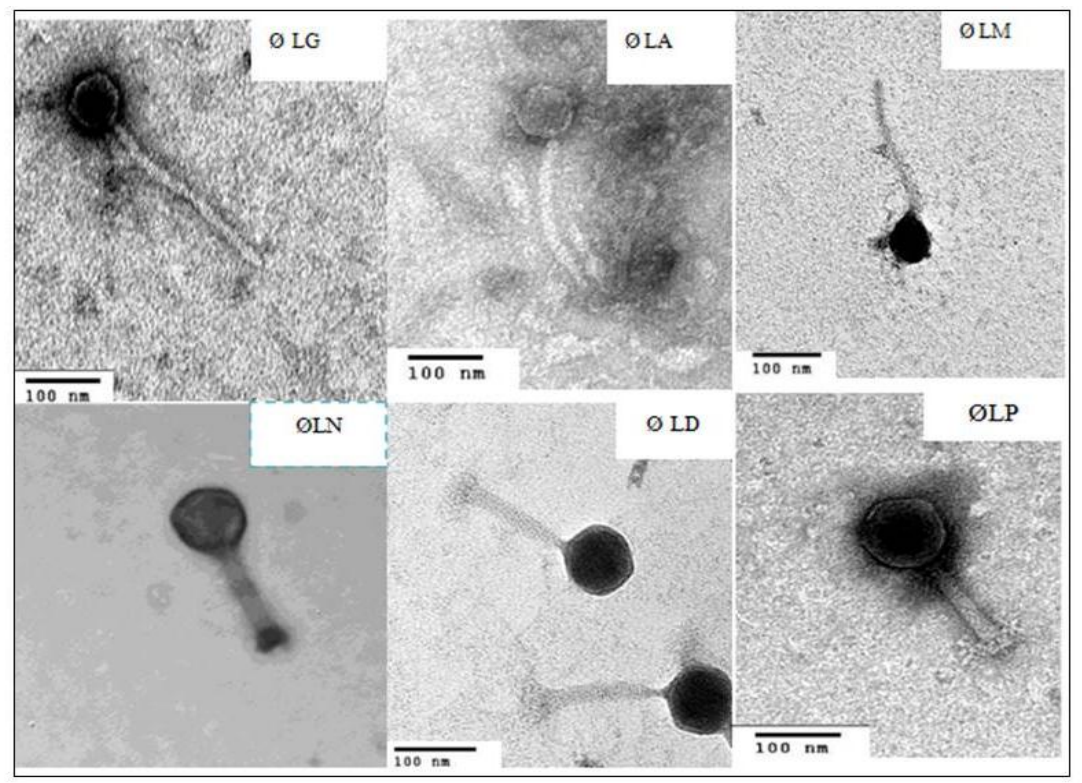

Fig. 1. Electron micrographs of Listeria phages ( ly stained with $2 \%$ uranyl acetate. 


\section{Listeria phages stability}

The effect of temperature on Listeria phages stability was studied as mentioned in the materials and methods. Results showed that the Listeria phages ØLG, ØLN, ØLA, ØLD, ØLM and ØLP were able to lysis the bacterial host up to $80^{\circ} \mathrm{C}$. All Listeria phages were inactivated when exposed to thermal treatment at $90 \stackrel{\circ}{\circ}$ for $10 \mathrm{~min}$. Results of LIV of Listeria phages showed that phages were survived and had high stability until 60 days at different temperatures $\left(25-30^{\circ} \mathrm{C}\right)$ as well as refrigerator $\left(4^{\circ} \mathrm{C}\right)$.

\section{Effect of pH degrees on Listeria phages}

Results revealed that, all Listeria phages didn't lose their abilities to lyse $L$. monocytogenes cells at $\mathrm{pH}$ ranged from 4.0 to 12 . Results indicated that the $L$. monocytogenes phages were stable in both of the alkaline and acidic conditions.

\section{Sensitivity of Listeria phages to UV radiation}

Results showed that Listeria phages didn`t lose their infectivity after exposure to the UV irradiation at distances of 35 and $53 \mathrm{~cm}$ from irradiation source for $90 \mathrm{~min}$.

\section{SDS-PAGE analysis of purified Listeria phages}

Results in Table (4) and illustrated in Fig. (2) showed the presence of variation among the protein patterns of Listeria phages determined via SDS-PAGE. Moreover, the protein bands were also varied in their densities. Results also showed a number of total protein bands of 10 . These bands were representing among the 6 Listeria phages with 5 or 6 bands out of the 10 protein bands. This variation was presented in either number of protein bands or molecular weights, which ranged from 28 to $87 \mathrm{kDa}$. The 10 total bands contained 5 bands representing structural proteins in $\varnothing L G$ with molecular weights of $\sim 87,70,45,37$ and $35 \mathrm{kDa}$. ØLN phage had five structural proteins with molecular weights of $\sim 68,45,35,33$ and 30 kDa. $\varnothing \mathrm{LA}$ phage had 6 bands (structural proteins) with molecular weights of $\sim 66,37,35,33,30$ and $28 \mathrm{kDa}$. ØLD phage had 6 structural proteins with molecular weights of $\sim 45,37,35,33,30$ and 28 kDa. ØLM phage had 5 bands (structural proteins) with molecular weight $\sim 66,45,37,33$ and $28 \mathrm{kDa}$. $\varnothing \mathrm{LP}$ phage had 6 structural proteins with molecu- lar weights of $\sim 66,45,35,33,30$ and $28 \mathrm{kDa}$. Different protein polymorphisms were recorded for 7 out of 10 with percentage $70 \%$. ØLG and ØLN phages appeared unique protein bands.

Table (5): Protein patterns of Listeria phages determined by SDS-PAGE analysis.

\begin{tabular}{|c|c|c|c|c|c|c|c|}
\hline \multirow{2}{*}{$\begin{array}{c}\mathrm{M}_{\mathrm{W}}(\mathrm{kDa}) \\
\text { of protein } \\
\text { bands }\end{array}$} & \multicolumn{6}{|c|}{ Phages } & \multirow{2}{*}{$\begin{array}{l}\text { Types of } \\
\text { protein } \\
\text { bands* }\end{array}$} \\
\hline & $\varnothing L G$ & $\varnothing L N$ & ØLA & $\varnothing L D$ & $\varnothing L M$ & ØLP & \\
\hline 87 & + & - & - & - & - & - & U \\
\hline 70 & + & - & - & - & - & - & U \\
\hline 68 & - & + & - & - & - & - & $U$ \\
\hline 66 & - & - & + & - & + & + & $P$ \\
\hline 45 & + & + & - & + & + & + & $P$ \\
\hline 37 & + & - & + & + & + & - & $P$ \\
\hline 35 & + & + & + & + & - & + & $P$ \\
\hline 33 & - & + & + & + & + & + & $P$ \\
\hline 30 & - & + & + & + & - & + & $P$ \\
\hline 28 & - & - & + & + & + & + & $P$ \\
\hline Total & 5 & 5 & 6 & 6 & 5 & 6 & 10 \\
\hline
\end{tabular}

(+): Present. (-): Absent. $M=$ Monomorphic. $P=$ Polymorphic. $\mathrm{U}=$ Unique.

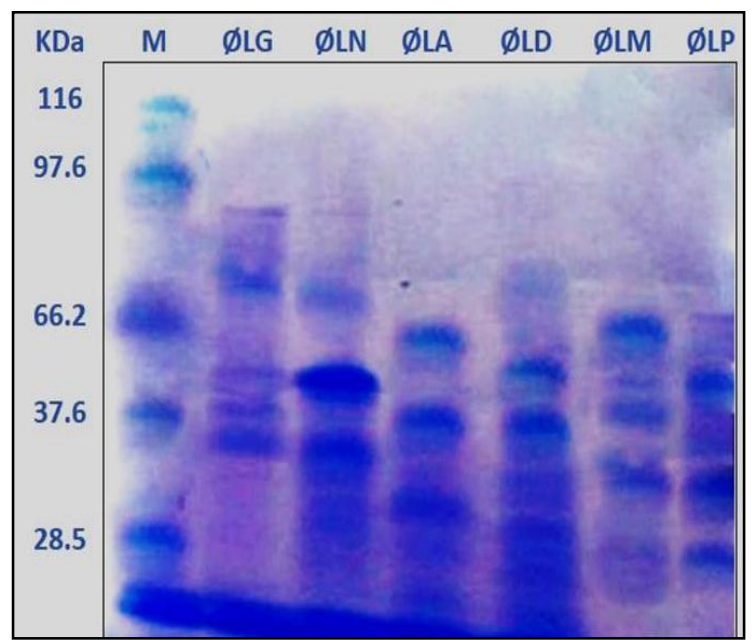

Fig. 2. SDS-PAGE analysis shows the protein patterns of Listeria phages (ØLG, ØLN, ØLA, ØLD, $\varnothing L M$ and $\varnothing L P)$.

\section{DISCUSSION}

Many water-borne pathogens, e.g. L. monocytogenes are zoonotic, they are responsible for infecting both humans and animals (Bridle, 2013). L. monocytogenes is an opportunistic human path- 
ogen, broadly distributed in the environment and transmitted to humans and animals through contaminated foods. It causes listeriosis, it is a severe disease which may possibly result in septicemia, meningitis, encephalitis, or loss of the fetus during pregnancy (Guenther et al 2009).

Bacteriophages are viruses that are responsible of infecting bacteria (Lossner and Rees, 2005).

In this investigation, six virulent phages specific to $L$. monocytogenes were isolated from the polluted irrigation and sewage water. Similar study was conducted by Akhtar et al (2017) who isolated $L$. monocytogenes phages from raw sewage samples, from water treatment plants. Also, both of Kim et al (2008) and Arachchi (2013) isolated Listeria phages from sewage and silage.

Listeria phage titers usually determine by the double layer agar technique and obtaining of the phage isolates by picking up single plaques from the plates resulting from the high dilutions of the phage as described by Arachchi (2013). In this study using the same techniques, Listeria phages forming clear circular plaques of $\leq 2$ to $3 \mathrm{~mm}$ in diameter with halo were isolated. Data agree with the results that found by Arachchi (2013) who isolated three phages forming plaques with narrow haloes from seafood processing plants.

Electron microscopy examination of negatively stained Listeria phage preparations of this investigation showed that $\varnothing \mathrm{LG}, \varnothing \mathrm{LA}$ and $\varnothing \mathrm{LM}$ belonging to family Siphoviridae while the other phages were belonging to family Myoviridae, this was based on the morphology of phage particles. Data of Klumpp and Loessner (2013) supported the experimental results. They stated that all Listeriaspecific phages are members of the Caudovirales, featuring the long and noncontractile tails of the Siphoviridae family, or the complex contractile tail of the Myoviridae family.

Different external physical and chemical factors such as: temperature, acidity and salinity change the viability and storage of bacteriophages, which may inactivate the phage through damage of its structural elements (head, tail and envelope), lipid loss, and/or DNA structural changes were reported by Ackermann et al (2004). Therefore, some physical characters of Listeria phages were studied to determine the effects of some factors on phages.

All isolated Listeria phages lost their infectivity after exposure to $90^{\circ} \mathrm{C}$ for $10 \mathrm{~min}$. The previous results didn't agree with that of Arachchi (2013) who stated that the three isolated phages in his study were more heat-labile since only LiMN4L survived up to $\approx 10 \%$ at $60^{\circ} \mathrm{C}$ for $10 \mathrm{~min}$. and the other two phages reduced to non-detectable levels within $10 \mathrm{~min}$. The difference between the tolerances of the phages generally was associated with the environment host from which they are derived.

Also, the previous studies of Jończyk et al (2011) investigating phage stability at various temperatures and have suggested that the ability of phages to remain stable in unsuitable temperatures which is varied within and among phage families. In this study, the results of stability of Listeria phages at room temperature and refrigerator reveled that Listeria phages were high stable and survived for at least 60 days at room temperature $\left(25-30^{\circ} \mathrm{C}\right)$ and refrigerator $\left(4^{\circ} \mathrm{C}\right)$ and this agree with that of Arachchi (2013) who investigated stability of Listeria phages during refrigerated storage and found that infectivity of his three phages remained stable for one year.

All Listeria phages didn`t lose its ability to lyse L. monocytogenes cells at $\mathrm{pH}$ ranged from 4.0 to 12.0. The results indicated that the Listeria phages are stable in both of the alkaline and acidic media. Results of this study was differed from that of Arachchi (2013) who mentioned that two Listeria phages were survived at $\mathrm{pH} 4.0-10.0$ while one phage was survived at $\mathrm{pH}$ 4.0-9.0 for $1 \mathrm{~h}$, and this means that the phages isolated in this study were more resistant to $\mathrm{pH}$ values than the others and that may be return to the fact that tolerance of bacteriophages was differing between them.

The high stability of the Listeria phages across a range of $\mathrm{pH}$, suggested that the Listeria phages have the potential to be successfully applied in foods and preparation surfaces which are exposed to acidic and neutral environments, as the Listeria phages remain stable and lytic under these conditions (Nonis, 2016).

In this work Listeria phages were exposed to UV irradiation at two different distances far from the source of UV. Listeria phages didn't lose their infectivity after exposure to UV irradiation. The results agreed with that of Jończyk et al (2011) who stated that tailed phages (as Listeria phages) were the most stable in contrary conditions. In addition to the phages with a large capsid as Listeria phages (100 nm in diameter) survived better than phages with a head $60 \mathrm{~nm}$ in diameter.

The results of SDS-PAGE analysis of Listeria phages showed that phages had 5-6 protein fragments with molecular weights of $66,45,37,35,33$ and $28 \mathrm{kDa}$ distributed among the six phages. 
Data of the present work didn`t agree with Loessner et al (1994) who generated individual protein profiles by SDS-PAGE of viral polypeptides. The major structural proteins of Listeria phages ranged in size from approximately 15 to $38 \mathrm{kDa}$. Protein compositions of Listeria phages permitted the differentiation of individual phages as well as the recognition and grouping of similar viruses.

The possibility of application of the virulent phages for controlling the $L$. monocytogenes in other experiments was recommended by this study.

\section{REFERENCES}

Ackermann, H.W., Tremblay, D. and Moineau, S. 2004. Long-term bacteriophage preservation. WFCC Newsletter, 38, 35-40.

Adams, M.H. 1959. Bacteriophages. Interscience Publishers: New York, USA, pp. 443-522.

Akhtar, M., Viazis, S., Christensen, K., Kraemer, P. and Diez-Gonzalez, F. 2017. Isolation, characterization and evaluation of virulent bacteriophages against Listeria monocytogenes. Food Control, 75, 108-115.

Arachchi, G.J.G. 2013. A study of natural lytic Listeria phages with decontaminating properties for use in seafood processing plants. Ph.D. Thesis, Institute of Food, Nutrition and Human Health, Massey University, Auckland, New Zealand. 199 p.

Basdew, I.H. and Laing, M.D. 2014. Stress sensitivity assays of bacteriophages associated with Staphylococcus aureus, causal organism of bovine mastitis. African Journal of Microbiology Research, 8(2), 200-210.

Borrego, J.J., Morifiigo, M.A., deVicente, A., Cornax, R. and Romero, P. 1987. Coliphages as an indicator of faecal pollution in water: Its relationship with indicator and pathogenic microorganisms. Water Res., 21, 1473-1480.

Bridle, H. 2013. Waterborne Pathogens: detection methods and applications. Elsevier B.V.: London, UK, $387 \mathrm{p}$.

Figrski, D.H. and Christensen, J.R. 1974. Functional characterization of the genes of bacteriophage TI. Virology, 69, 397-407.

Goodridge, L., Gallaccio, A. and Griffiths, W.M. 2001. Morphological, host range, and genetic characterization of two coliphages. Applied and Environmental Microbiology, 69, 53645371.

Guenther, S., Huwyler, D., Richard, S. and Loessner, M.J. 2009. Virulent bacteriophage for efficient biocontrol of Listeria monocytogenes in ready-to-eat foods. Applied and Environmental Microbiology, 75(1), 93-100.

Hagens, S. and Loessner, M.J. 2014. Phages of Listeria offer novel tools for diagnostics and biocontrol. Frontiers in Microbiology, 159(5),16.

Jamallueen, N., Johnson, R.P., Friendship, R., Kropinski, A.M., Lingonhr, E.J. and Glyes, C.L. 2007. Isolation and characterization of nine bacterioophages that lyse 0149 enterotoxigenic Escherichia coli. Veterinary Microbiology, 124, 47-57.

Jończyk, E., Kłak, M., Międzybrodzki, R. and Górski, A. 2011. The influence of external factors on bacteriophages-review. Folia Microbial., 56, 191-200.

Kim, J., Siletzky, R.M. and Kathariou, S. 2008. Host ranges of Listeria-specific bacteriophages from the turkey processing plant environment in the United States. Applied and Environmental Microbiology, 74, 6623-6630.

Klumpp, J. and Loessner, M.J. 2013. Listeria phages genomes, evolution, and application. Bacteriophage, 3(3), 1-8.

Laemmli, U. 1970. Cleavage of structural proteins during the assembly of the head of bacteriophage T4. Nature, 227, 680-685.

Loessner, M.J. and Rees, C.E.D. 2005. Listeria phages: Basics and applications. In: Phages: their role in bacterial pathogenesis and biotechnology (Waldor, M.K.; Friedman, D.I. and Adhya, S.L., Eds), pp. 362-379, ASM Press, Washington D.C., USA.

Loessner, M.J., Estela, L.A, Zink, R. and Scherer, S. 1994. Taxonomical classification of 20 newly isolated Listeria bacteriophages by electron microscopy and protein analysis. Intervirology, 37(1), 1-5.

Madigan, M. and Martinko J., eds. 2005. Brock Biology of Microorganisms (11 ${ }^{\text {th }}$ ed.). Prentice Hall. ISBN 0-13-144329-1., J. of International Microbiology, 8, 149-152

Nonis, J. 2016. Bacteriophage as a biocontrol tool for foodborne pathogens. M.Sc. Thesis, University of Canterbury. 107 p.

Sambrook, J., Fritschi E.F. and Maniatis T. 1989. Molecular cloning: a laboratory manual, Cold Spring Harbor Laboratory Press, New York, USA, pp. 312-325.

Schmid, B., Klumpp, J. Raimann, E., Loessner, M.J., Stephan, R. and Tasara, T. 2009. Role of cold shock proteins in growth of Listeria monocytogenes under cold and osmotic stress 
conditions. Applied and Environmental Microbiology, 75, 1621-1627.

Schmuki, M.M., Erne, D., Loessner, M.J. and Klumpp, J. 2012. Bacteriophage P70: unique morphology and unrelatedness to other Listeria bacteriophages. J. Virol. 86, 13099-13102.

Taj, M.K., Ling, J.X., Bing, L.L., Qi, Z., Taj, I., Hassani, T.M., Samreen, Z. and Yunlin, W. 2014. Effect of dilution, temperature and $\mathrm{pH}$ on the lysis activity of T4 phage against E. coli bl21. The J. of Animal and Plant Sciences, 24 (4), 1252-1255.

Yutaka, S., Naohira, S., Yohei, D. and Yoshichika, A. 2004. Escherichia coli Producing CT $\mathrm{X}$-mz-betalactamase in cattle in Japan. Emerging Infectious Diseases Journal, 10(1), 6975. 
المؤتمر الرابع عشر لبحوث التنمية الزراعية،

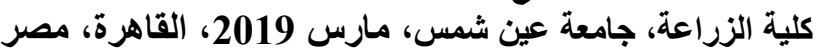

مجلا(27)، عدد (1)، عدد خاص مارس، مارس، 183-175، 2019

Website: http://strategy-plan.asu.edu.eg/AUJASCl/

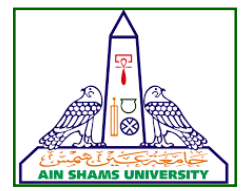

\section{الخصائص الفيزيائية والكيميائية لبعض فاجات الليستريا}

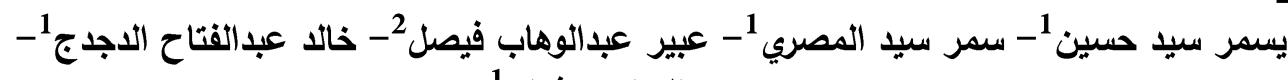

[16]

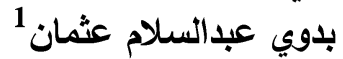

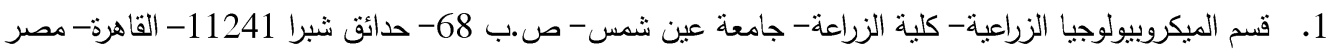

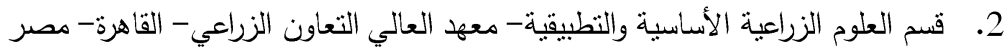

*Corresponding author: samar_sayed@agr.asu.edu.eg

Received 24 February, 2019,

Accepted 9 April, 2019

الفاقدة لنشاط الفاجات هى 80 درجة مئوية. كما ظلت

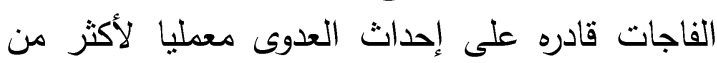

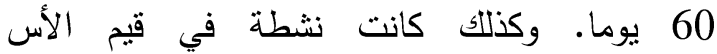
الهيدروجيني و اللتى نتراوح ما بين 4.0 إلى في 12.0. تفقد فاجات الليستريا قدرتها على التحلل بعد التعرض لئن

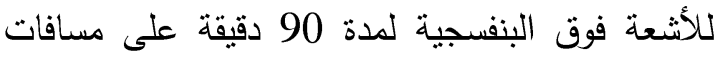

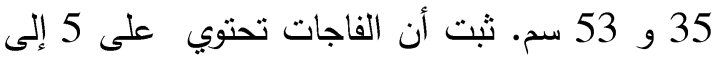
6 بروتينات هيكلية وتم تقدير أوزانها الجزيئية باستخدام

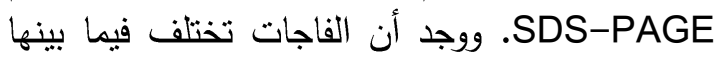
في بوليمورفيزم بروتيناتها.

الكلمات الدالة: فاجات الليستيري ، مياه الصرف

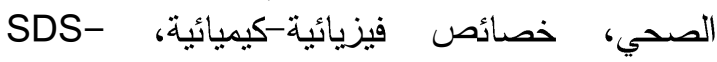

.PAGE

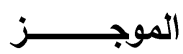

نتنقل بكتيريا الـ Listeria monocytogenes وهي بكتيريا مسببة للأمراض عن طريق الغذاء وتسبب أنسا

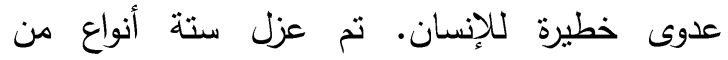
الفيروسات التي تصيب الليستريا مونوسيتوجينيس من

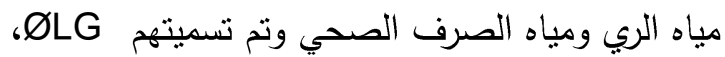
ØLA إكثار الفاجات وتركيزها عن طريق الطرد المركزى

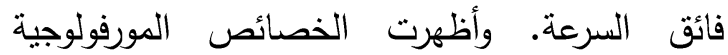
لفاجات الليستيريا بأنها من الفاجات ذات التاتيل، الذيل،

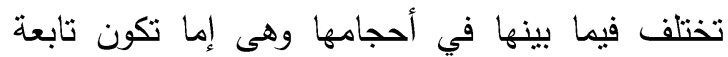
لعائلة الـ Siphoviridae أو الـ Myoviridae.

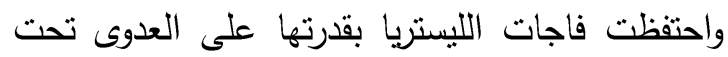
ظروف درجات الحرارة المختلفة و كانت درجة الحرارة العات التهات 